\title{
Studi Keanekaragaman dan Kelimpahan Crustacea pada Area Padang Lamun Pantai Bama dan Kajang, Taman Nasional Baluran
}

\author{
Venora Elisa Launa Rifsanjani dan Farid Kamal Muzaki \\ Departemen Biologi, Fakultas Ilmu Alam, Institut Teknologi Sepuluh Nopember (ITS) \\ e-mail: rm_faridkm@bio.its.ac.id
}

\begin{abstract}
Abstrak-Salah satu daya tarik wisata terbesar di Taman Nasional Baluran adalah kawasan pantainya, termasuk Pantai Bama dan Kajang. Kedua pantai ini memiliki area padang lamun yang cukup luas dan diperkirakan akan terdampak oleh kegiatan wisata. Tujuan dilakukannya penelitian ini adalah untuk mengetahui keanekaragaman dan kelimpahan crustacea yang berada di Pantai Baman sebagai pantai yang ramai pengunjungn dan pantai Kajang sebagai pantai yang sepi pengunjung. Variabel pengamatan adalah kelimpahan dan keanekaragaman crustacea pada ara padang lamun yang diamati dengan menggunakan metode belt transect yang dimodifikasi dengan enam kali replikasi, data tersebut kemudian dianalisis dengan analisi statistik menggunakan UjiT dua sampel bebas. Hasil yang didapat dari penelitian ini, crustacea di kedua lokasi didominansi oleh anggota famili Diogenidae (hermit crab). Kelimpahan total crustacea di Pantai Bama (rata-rata 51.8 individu/150m²) secara signifikan lebih tinggi dibandingkan dengan Pantai Kajang (rata-rata 18.8 individu $/ 150 \mathrm{~m}^{2}$ ) dan tidak terdapat perbedaan kekayaan jenis antara kedua lokasi tersebut. Nilai rata-rata indeks diversitas Shnnaon-Wiener (H') komunitas crustacea di Pantai Bama berkisar antara 1,03-1,30 sedangkan di Pantai Kajang antara 0,24-1,36.
\end{abstract}

Kata Kunci-kekayaan jenis, kelimpahan, keanekaragaman, komunitas crustacea, padang lamun, Pantai Bama dan Kajang.

\section{PENDAHULUAN}

ALAH satu potensi dari wilayah pesisir Indonesia adalah pada sektor wisata bahari, dimana Indonesia memiliki pariwisata bahari yang diakui dunia dengan keberadaan 21 wisata potensial, dan keanekaragaman hayati yang sangat tinggi sebagai daya tarik pengembangan kegiatan ekowisata atau biasa dikenal sebagai ecotourism. Wisata merupakan suatu bentuk pemanfaatan sumber daya alam yang mengandalkan jasa alam untuk kegiatan manusia, kegiatan manusia untuk kepentingan wisata sendiri disebut sebagai pariwisata [1]. Salah satu subkomponen dari pariwisata adalah ekowisata. Ekowisata merupakan sistem pariwisata berkelanjutan yang mengusung konsep pengembangan sektor pariwisata berkelanjutan [2]. The Australian Commission on National Ecotourism Strategy menyebutkan ekowisata sebagai wisata berbasis alam yang meningkatkan fungsi pendidikan dan pemahaman terhadap lingkungan yang bertujuan untuk keberlanjutan ekologi, namun saat ini seringkali ditemui kerusakan area konservasi dikarenakan adanya perkembangan area tersebut menjadi kawasan ekowisata [2].
Taman Nasional Baluran (TN Baluran) yang terletak di Kabupaten Situbondo, Jawa Timur merupakan salah satu kawasan wisata yang terkenal di Indonesia. TN Baluran merupakan kawasan konservasi yang cukup kompleks, dimana pada area perairannya memiliki ekosistem mangrove, terumbu karang, lamun, ikan karang serta biota lainnya. TN Baluran awalnya dibentuk sebagai suaka marga satwa pada tahun 1937. Berdasarkan SK. Menteri Kehutanan No. 279/Kpts.-VI/1997 tanggal 23 Mei 1997 luas TN Baluran mencapai $25.000 \mathrm{Ha}$, dengan luas wilayah perairan mencapai $1.063 \mathrm{Ha}$. Sebagian wilayah perairan ini dibuka sebagai area wisata bagi pengunjung, hal ini dikarenakan dengan adanya wisata diharapkan wilayah tersebut memiliki nilai ekonomi lebih bagi masyarakat sekitar tanpa harus merusak ekositem asli.

Wilayah perairan TN Baluran sebagian besar tergolong dalam zona Perlindungan Bahari, namun ada beberapa wilayah yang digolongkan dalam zona pemanfaatan. Berdasarkan (SK Dirjan PHKA Nomor: SK/228/IVSet/2012) salah satu wilayah perairan bahari yang tergolong dalam Zona Pemanfaatan yaitu Pantai Bama dan Pantai Kajang. Jumlah pengunjung $\mathrm{TN}$ Baluran tiap tahunnya mencapai 14.000 [3] dengan jumlah pengunjung Pantai Bama lebih banyak daripada Pantai Kajang.

Kegiatan pariwisata yang biasa dilakukan oleh pengunjung TN Baluran lebih banyak dihabiskan pada area pantai yang dekat dengan daratan baik berupa kegiatan menyelam (diving), snorkeling, berperahu (canoing), atau sekedar berjalan-jalan di area sekitar pantai [4]. Pada area tersebut terdapat hamparan padang lamun yang luas $( \pm 6,7$ ha) dan memiliki tipe vegetasi campuran ( \pm 7 spesies) [5].

Padang lamun diketahui merupakan komunitas penyusun ekosistem lamun yang memiliki fungsi ekologis tinggi serta memiliki biodiversitas biota laut yang tinggi pula yang biasanya digunakan sebagai tempat mencari makan oleh biota laut sebagai tempat mencari makanan [6]. Lamun atau seagrass adalah tanaman berbunga (Angiospermae) yang hidup di laut yang ditemukan hampir di seluruh wilayah pesisir [7].

Pada ekosistem lamun sendiri sering kali dijumpai beberapa biota laut yang hidup berasosiasi dengan lain, salah satunya adalah Crustacea. Crustacea sendiri merupakan subfilum dari Arthropoda yang sebagian besar hidup pada wilayah perairan yang didalamnya termasuk lobster, udang, kepiting, teritip [8]. Crustacea yang ditemukan hidup berasosiasi pada area padang lamun biasanya hidup sebagai 
pemakan detritus dan rimpang lamun, memakan daun lamun, dan beberapa kepiting dengan ukuran yang besar memakan moluska, polychaeta, dan alga yang menempel pada lamun [9]. Selain itu ada pula beberapa crustacea yang memakan hewan-hewan kecil yang menempel pada daun lamun, selain itu lamun juga berperan sebagai tempat tinggal dari beberapa jenis crustacea [10].

Pemanfaatan dua pantai tersebut sebagai area wisata bahari dengan konsep ekowisata diperkirakan berpotensi memberikan pengaruh terhadap biota perairan tersebut. Adanya aktivitas manusia tentunya akan memiliki dampak pada biota laut yang berada pada area lamun. Berdasarkan [11]adanya faktor trampling ini akan sangat berbahaya bagi rumput laut dan lamun serta fauna-fauna yang berasosiasi dengan rumput laut dan lamun pada lingkungan perairan. Penelitian serupa juga dilakukan oleh [12] mengatakan adanya penurunan kelimpahan udang yang dikarenakan adanya kegiatan antropogenik yang intensif [13].

Penelitian ini ditujukan untuk mengetahui seberapa besar mengetahui kelimpahan dan keanekaragaman jenis Crustacea di Pantai Bama dan Kajang, Taman Nasional Baluran.

\section{METODOLOGI}

\section{A. Lokasi dan Waktu Penelitian}

Penelitian dilaksanakan pada periode Juni 2017 hingga Januari 2018. Pengambilan sampel variabel fisik, kimia dan biologi lingkungan dan pengamatan crustacea dilakukan di area padang lamun Pantai Bama dan Kajang, Taman Nasional Baluran, Situbondo - Jawa Timur. Pantai Bama merepresentasikan lokasi pantai wisata dengan jumlah pengunjung lebih tinggi sedangkan Pantai Kajang sebagai representasi pantai wisata dengan jumlah pengunjung yang lebih rendah.

\section{B. Pengukuran Parameter Fisik dan Kimia Perairan}

Parameter fisik dan kimia perairan di Pantai Bama dan Kajang yang diukur adalah suhu, salinitas, oksigen terlarut (DO) dan derajat keasaman (pH) serta kandungan materi organik total (Total Organic Matter/TOM). Pengukuran setiap parameter kecuali TOM dilakukan secara in situ pada enam unit transek yang menjadi pengulangan atau replikasi pada setiap lokasi (Pantai Bama dan Kajang).

Metode yang digunakan dalam pengukuran TOM berdasarkan SNI 06-6989.22-2004. Analisis sampel dilakukan di Laboratorium Rekayasa Proses Departemen Teknik Lingkungan Fakultas Teknik Sipil dan Perencanaan ITS.

\section{Pengukuran Persen Penutupan dan Kerapatan Lamun}

Variabel kerapatan dan penutupan setiap jenis lamun diukur sesuai metode dalam [14] yang dimodifikasi. Pada setiap transek untuk pengamatan Crustacea dibuat 10 unit kuadrat 1x1 meter. Pengukuran menggunakan kuadrat 50x50 $\mathrm{cm}$ yang terbagi kedalam 25 unit grid ukuran 10x10 cm.

Analisis data kerapatan lamun dilakukan dengan menggunakan persamaan dalam [14];

$$
D i=\frac{n i}{A}
$$

Di : kerapatan jenis ke-i (tegakan $/ \mathrm{m}^{2}$ )

ni : jumlah total individu dari jenis ke-i

A : luas area total pengambilan contoh $\left(\mathrm{m}^{2}\right)$

Perkiraan persentase penutupan setiap jenis lamun berdasarkan [14] dengan persamaan sebagai berikut.

$$
C=\frac{\Sigma(M i \times f i)}{\Sigma f}
$$

C : persen penutupan suatu jenis lamun (\%)

$\mathrm{Mi}$ : nilai tengah persentase kelas jenis ke-i

fi : frekuensi jenis jenis ke-i

f : total frekuensi (jumlah total grid)

Perkiraan persentase penutupan setiap jenis lamun mengacu pada kriteria seperti pada Tabel 1 berikut.

Tabel 1.

Perkiraan Persentase Tutupan Lamun

\begin{tabular}{llll}
\hline \hline Kelas & Jumlah substrat tertutupi & $\begin{array}{l}\text { \% substrat } \\
\text { tertutupi }\end{array}$ & $\begin{array}{l}\text { Mid point \% } \\
(\mathrm{M})\end{array}$ \\
\hline 5 & $1 / 2$ sampai seluruhnya & $50-100$ & 75 \\
4 & $1 / 4$ sampai $1 / 2$ & $25-50$ & 37,5 \\
3 & $1 / 8$ sampai $1 / 4$ & $12,5-25$ & 18,75 \\
2 & $1 / 16$ sampai $1 / 8$ & $6,25-12,5$ & 9,38 \\
1 & Kurang dari $1 / 16$ & $<6,25$ & 3,13 \\
0 & Tidak ada & 0 & 0 \\
\hline \hline
\end{tabular}

\section{Pengamatan Komunitas Crustacea}

Pengamatan crustacea pada area padang lamun Pantai Bama dan Kajang dilakukan dengan metode belt transect (transek sabuk) yang dimodifikasi. Posisi transek sedemikian rupa sehingga mewakili area dari batas awal terdapat lamun hingga ujung batas keberadaan lamun.

Setiap transek berukuran panjang 25 meter dan lebar 1 meter, kemudian pada tiap jarak 5 meter dibuat transek cabang sepanjang 5 meter dengan lebar tetap 1 meter [15]. Pada setiap lokasi, dibuat 6 unit transek sebagai replikasi.

Setiap jenis crustacea yang terdapat didalam transek diidentifikasi dan dihitung kelimpahannya. Identifikasi jenis crustacea menggunakan beberapa literatur seperti [16][17].

\section{E. Analisis Data}

Penelitian bersifat deskriptif kuantitatif. Kekayaan jenis crustacea direpresentasikan sebagai jumlah jenis crustacea yang terdapat dalam tiap transek. Perbedaan kekayaan jenis dan kelimpahan crustacea di padang lamun Pantai Bama dan Kajang dianalisis dengan uji $\mathrm{T}$ dua sampel bebas (independent samples $T$-test) pada $\mathrm{p}=0.05$.

Analisis tingkat keanekaragaman menggunakan indeks keanekaragaman jenis Shannon-Wiener (H') dan indeks kemerataan jenis Pielou (J) sebagai berikut;

Indeks Shannon-Wiener (H')

$$
H^{s}=-\sum\left(\frac{n i}{N} \times \ln \frac{n i}{N}\right)
$$


Indeks Pielou (J)

$$
I=\frac{H^{f}}{\ln (S)}
$$

ni : kelimpahan individu jenis ke-i

$\mathrm{N}$ : kelimpahan total seluruh jenis

S : jumlah total jenis

\section{HASIL DAN PEMBAHASAN}

\section{A. Parameter Fisik dan Kimia Lingkungan}

Parameter fisik dan kimia perairan di Pantai Bama dan Kajang yang diukur adalah suhu, salinitas, oksigen terlarut (DO) dan derajat keasaman $(\mathrm{pH})$ dengan hasil seperti pada Tabel 2 sebagai berikut;

Tabel 2.

Hasil Pengukuran Parameter Fisika-Kimia Perairan

\begin{tabular}{lllll}
\hline \multirow{2}{*}{ Parameter } & \multirow{2}{*}{ Satuan } & \multicolumn{3}{c}{ Nilai } \\
\cline { 3 - 5 } & & Bama & Kajang & BM \\
\hline \multirow{2}{*}{ Suhu } & ${ }^{\circ} \mathrm{C}$ & 29 & 30 & $28-30$ \\
Salinitas & $\%$ o & 33 & 33 & $33-34$ \\
Dissolved Oxygen & $\mathrm{mg} / \mathrm{L}$ & 6,8 & 7,1 & $>5$ \\
$\mathrm{pH}$ & - & 7,6 & 7,8 & $7-8,5$ \\
\hline \hline
\end{tabular}

Keterangan: BM: Baku mutu berdasarkan Lampiran III KepMen LH Nomor 51 Tahun 2004

Berdasarkan Tabel 2 tersebut diatas, besaran atau nilai parameter fisik-kimia lingkungan perairan di kedua lokasi masih memenuhi kriteria baku mutu untuk biota laut berdasarkan Lampiran III KepMen LH Nomor 51 Tahun 2004. Antara kedua lokasi juga tidak menunjukkan perbedaan nilai parameter lingkungan dan dapat diasumsikan bahwa padang lamun Pantai Bama dan Kajang memiliki kisaran parameter lingkungan yang tidak berbeda, yang mana semua parameter terukur masih mendukung untuk kehidupan crustacea.

Pada penelitian ini juga dilakukan pengukuran terhadap kandungan materi organik yang terdapat dalam sedimen. Sedimen yang didominansi oleh butir sedimen yang berukuran lebih kecil umumnya memiliki kandungan materi organik yang lebih inggi bila dibandingkan dengan sedimen dengan dominansi oleh butir sedimen yang berukuran besar [18]. Hasil dari analisis tipe sedimen yang dilakukan pada masing-masing transek pada tiap lokasi disajikan dalam Tabel 3.

Tabel 3.

Hasil Pengukuran Parameter Total Organic Matter (TOM)

\begin{tabular}{ccccc}
\hline \hline No & Lokasi & & Kadar Organik (\%) & Rata-rata \\
\hline \multirow{4}{*}{1} & & T1 & 3,38 & \\
& \multirow{4}{*}{ Bama } & T2 & 3,61 & \\
& & T3 & 3,98 & 3,245 \\
& & T4 & 3,34 & \\
& & T5 & 2,74 & \\
& & T6 & 2,42 & \\
& & T1 & 3,24 & \\
\multirow{4}{*}{2} & Kajang & T2 & 3,57 & \\
& & T3 & 4,49 & \\
& & T4 & 3,15 & \\
& & T5 & 2,61 & \\
\hline \hline
\end{tabular}

Perhitungan TOM pada Tabel 3 menunjukkan kisaran TOM pada Pantai Bama adalah 2,42-3,98\% dengan rata-rata sebesar 3,245\% sedangkan pada Pantai Kajang berkisar 2,23-4,49\% dengan rata-rata sebesar 3,215\%. Bahan organik yang ditemukan pada perairan umumnya berasal dari tumbuhan atau hewan akuatik yang telah diuraikan oleh detritus. Makrozoobentos melakukan perombakan bahan organik tersebut dan dipecah untuk menghasilkan energi beupa makanan yang digunakan untuk mempertahankan kelangsungan hidupnya [19].

\section{B. Persen Penutupan dan Kerapatan Lamun}

Parameter biologi yang diukur pada penelitian ini adalah persen penutupan dan kerapatan lamun. Persen luas tutupan lamun pada lokasi Bama berkisar antara 52.075\% - 82.06\%, sementara untuk kerapatan lamun lokasi Bama 98.89 tegakan $/ \mathrm{m}^{2}-134.78$ tegakan $/ \mathrm{m}^{2}$. Persen luas tutupan lamun ada lokasi Kajang berkisar antara $60.58 \%$ - $80.66 \%$, sementara kerapatan lamun pada lokasi ini berkisar antara 110.92 tegakan $/ \mathrm{m}^{2}-130.63$ tegakan $/ \mathrm{m}^{2}$. Berdasarkan nilai tersebut, tampak bahwa nilai persen penutupan dan kerapatan lamun sedikit lebih tinggi pada lokasi Kajang.

Spesies lamun yang ditemukan pada kedua lokasi adalah Enhalus acoroides, Thalassia hempricii, Cymodocea rotutundata dan Halodule pinifolia. Sementara spesies Syringodium isoetifolium hanya ditemukan di Kajang.

Total kerapatan lamun didominasi oleh spesies En. acoroides di kedua pantai dengan nilai tegakan sebesar 64,25 dan $64,22 \mathrm{ind} / \mathrm{m}^{2}$; kemudian spesies yang menduduki kerapatan kedua terbesar setelahnya adalah spesies $T h$. hemprichii dengan nilai 21,99 dan $23,79 \mathrm{ind} / \mathrm{m}^{2}$ pada Bama dan Kajang. Sedangkan spesies lain menempati nilai kerapatan berturut-turut untuk Bama dan Kajang adalah $C$. rotundata sebesar 18,58 dan $14,55 \mathrm{ind} / \mathrm{m}^{2} ; H$. ovalis sebesar 30,6 dan $5,65 \mathrm{ind} / \mathrm{m}^{2} ; H$. pinifolia sebesar 11,1 dan 11,56 $\mathrm{ind} / \mathrm{m}^{2}$. Untuk spesies $S$. isoetifolium yang hanya ditemukan di pantai Kajang memiliki kerapatan sebesar 2,6 ind $/ \mathrm{m}^{2}$.

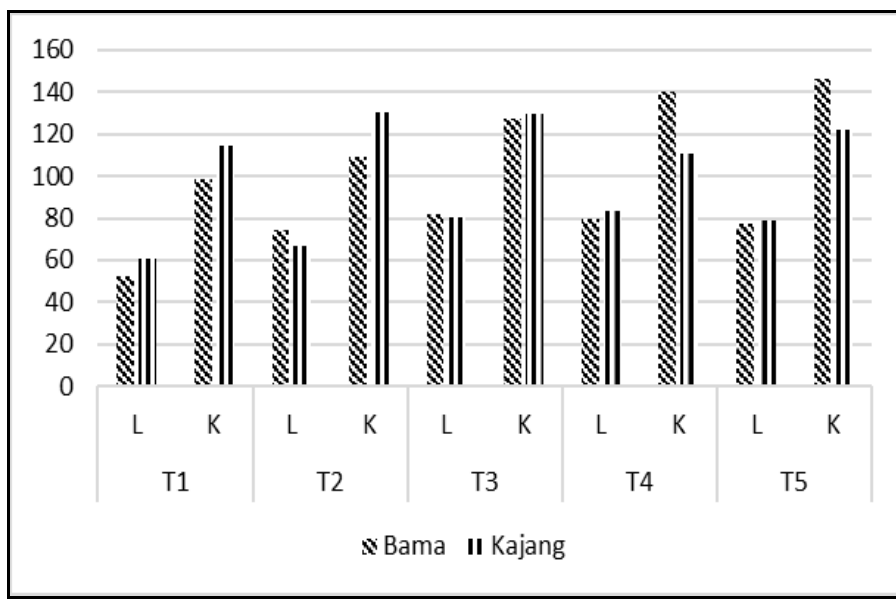

Keterangan: L. luas penutupan; K. kerapatan; T. transek Gambar 1. Grafik kerapatan (dalam individu/m²) dan penutupan (dalam \%) lamun di Pantai Bama dan Kajang

Tabel 4.

Rata-rata Penutupan dan Kerapatan Setiap Jenis Lamun di Pantai Bama dan Kajang

\begin{tabular}{lllll}
\hline \hline \multirow{2}{*}{ Species } & \multicolumn{2}{c}{ Kerapatan $\left(\mathrm{-m}^{2}\right)$} & \multicolumn{2}{c}{ Penutupan (\%) } \\
\cline { 2 - 5 } & Bama & Kajang & Bama & Kajang \\
\hline Enhalus acoroides & 64,25 & 64,22 & 19,4 & 26,7 \\
\hline \hline
\end{tabular}




\begin{tabular}{lllll}
\hline \hline Thalassia hemprichii & 21,99 & 23,79 & 22,7 & 22,35 \\
Cymodocea rotundata & 18,58 & 14,55 & 20,87 & 10,77 \\
Halodule pinifolia & 11,1 & 11,56 & 9,77 & 9,32 \\
Syringodium isoetifolium & 0 & 2,6 & 0 & 0,45 \\
Halophila ovalis & 30,6 & 5,65 & 4,34 & 3,48 \\
\hline \hline
\end{tabular}

Persen tutupan dan kerapatan padang lamun akan mempengaruhi besaran manfaat ekologis padang lamun. Padang lamun menyediakan berbagai macam fungsi dimana lamun menyediakan habitat bagi organisme yang tidak dapat hidup di dasar perairan tanpa adanya vegetasi, kanopi daun, jaringan rimpang dan akar lamun memberikan tambahan tempat pelekatan bagi organisme epifit. Selain itu, struktur tiga dimensi lamun menciptakan tempat persembunyian untuk menghindari predasi yang menyebabkan, kelimpahan dan keragaman fauna dan flora yang hidup di padang lamun secara konsisten lebih tinggi daripada daerah yang tidak bervegetasi lamun.

Secara umum, tidak terdapat perbedaan dalam hal kerapatan dan persentase penutupan lamun di Pantai Kajang dan Bama, meskipun beberapa hasil penelitian terdahulu menyebutkan adanya korelasi negatif antara persen penutupan dan kerapatan lamun dengan tingkat aktivitas antropogenik. Kerusakan dan kehilangan luasan padang lamun telah banyak didokumentasikan dengan baik dan penyebabnya dapat karena bencana alam dan aktivitas manusia [20] [13][21].

Crustacea sendiri umumnya hidup di sela-sela daun dan tegakan lamun, karena lamun berfungsi sebagai tempat mencari makan bagi crustacea [22] serta tempat tinggal berbagai biota laut khususnya crustacea seperti kepiting, kelomang ataupun kerang-kerangan [23].

\section{Komposisi Jenis Crustacea}

Penelitian yang dilakukan di Pantai Bama dan Kajang menunjukkan hasil bahwa pada kedua pantai ini memiliki kekayaan jenis yang hampir sama dengan ditemukannya 7 spesies dari 3 famili yang sama dengan kelimpahan masingmasing spesies dan famili yang berbeda (Gambar 2).

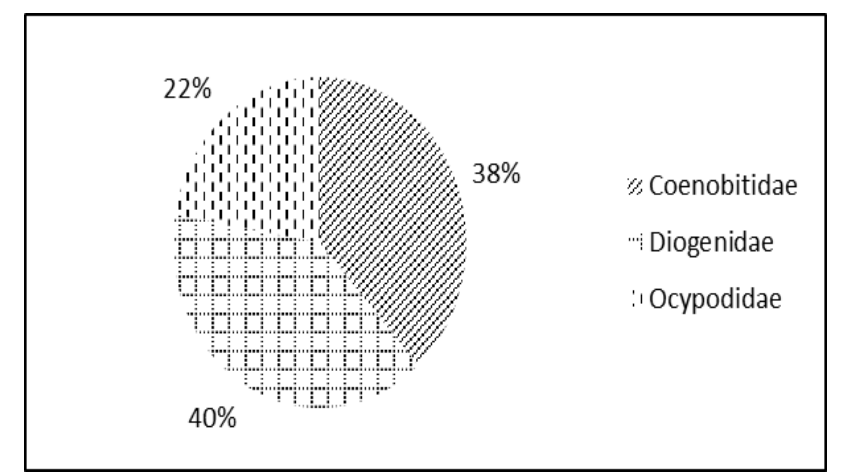

Gambar 2. Diagram kelimpahan crustacea berdasarkan famili di padang lamun Pantai Bama dan Kajang

Sebagian besar jenis crustacea yang ditemukan pada kedua lokasi adalah kelompok kelomang (hermit crab) dari famili Diogenidae dan Coenobitidae. Terdapat empat jenis Diogenidae yaitu Calcinus latens, Clibanarius elongatus, Clibanarius rugosus dan Dardanus megistos. Pada famili Coenobitidae dijumpai jenis Coenobita cavites dan Coenobita rugosus. Famili crustacea lain yang ditemukan adalah Ocypodidae yang diwakili oleh jenis Uca spp dan

\section{Ocypode sp.}

Pada penelitian famili yang paling banyak ditemukan adalah famili Diogenidae yang mencapai $40 \%$ atau 138 individu dari total kelimpahan crustacea pada kedua pantai tersebut, sedangkan famili yang paling sedikit kelimpahannya adalah Ocypodidae.

Hasil identifikasi yang dilakukan membuahkan hasil dimana pada Pantai Bama ditemukan 259 individu crustacea dengan komposisi $41 \%$ merupakan spesies Calcinus latens dengan jumlah 106 individu, 31\% merupakan spesies Coenobita cavipes dengan jumlah sebanyak 80 individu, $20 \%$ merupakan spesies Coenobita rugosus dengan jumlah sebanyak 51 individu, 5\% merupakan Clibanarius elongatus dengan jumlah sebanyak 14 individu, 2\% merupakan spesies dari Uca spp. dengan jumlah sebanyak 4 individu, 1\% merupakan spesies Dardanus magistos dengan jumlah sebanyak 2 individu, $1 \%$ bagian adalah spesies Ocypode sp. sebanyak 2 individu.

Pada Pantai Kajang ditemukan 94 individu crustacea dengan komposisi $71 \%$ adalah spesies Ocypode sp. sebanyak 67 individu, $10 \%$ merupakan spesies Calcinus latens sebanyak 9 individu, $8 \%$ merupakan spesies Coenobita cavipes dengan jumlah sebanyak 7 individu, 5\% merupakan spesiaes dari Uca spp dengan jumlah sebanyak 5 individu, 3\% merupakan spesies Clibanarius elongatus sebanyak 3 individu, 3\% merupakan spesies Coenobita rugosus dengan jumlah sebanyak 3 individu.

Perbandingan komposisi jenis dan famili crustacea pada kedua lokasi yaitu Pantai Bama dan Kajang menunjukkan bahwa anggota famili Diogenidae adalah yang paling melimpah dan dapat dijumpai pada kedua lokasi kecuali jenis Dardanus megistos yang hanya dijumpai di Pantai Bama.

Berdasarkan [14], sebagian besar famili Diogenidae hidup berasosiasi dengan tumbuhan lamun. Penelitian serupa yang dilakukan oleh [24] menunjukkan adanya asosiasi antara lamun dengan crustacea di padang lamun di Teluk Lampung. Kelomang banyak ditemukan melekat pada daun dan tunas lamun atau pantai berpasir yang banyak ditumbuhi lamun [24].

Jumlah jenis dan komposisi jenis crustacea pada penelitian lebih rendah bila dibandingkan dengan hasil penelitian serupa oleh [24] yang menemukan 57 jenis crustacea dari 15 famili di Teluk Lampung. [10] menemukan 12 jenis crustacea dari Teluk Kuta dan 14 jenis dari Teluk Gerupuk, Lombok.

Perbedaan jumlah jenis dan komposisi tersebut diperkirakan disebabkan oleh perbedaan metode sampling. Pada penelitian ini sampling dilakukan dengan teknik visual census atau pengamatan dan koleksi langsung yang bersifat tidak merusak (non-destruktif) sedangkan penelitian oleh [24] menggunakan alat pukat pantai (beach seine) untuk mencakup area yang luas sementara penelitian oleh [10]menggunakan alat corer dan jala seser.

Pada penelitian ini juga tidak ditemukan crustacea dari famili Penaeidae, Portunidae, Calappidae, Xanthidae, Palaemonidae dan Squillidae yang umumnya juga ditemukan di kawasan padang lamun [9][10] [24][25]. Belum diketahui dengan pasti faktor yang menyebabkan tidak dijumpainya jenis-jenis tersebut di lokasi Pantai Bama dan Kajang; 
apakah disebabkan oleh faktor antropogenik, perbedaan komposisi jenis lamun, perbedaan alat tangkap atau adanya faktor yang lainnya.

\section{Jumlah Jenis dan Kelimpahan Crustacea}

Kelimpahan crustacea yang dilakukan di Pantai Bama dan Pantai Kajang menunjukkan hasil dimana Pantai Bama memiliki rata-rata kelimpahan yang lebih tinggi daripada Pantai Kajang. Hal tersebut ditampilkan dalam Gambar 3.

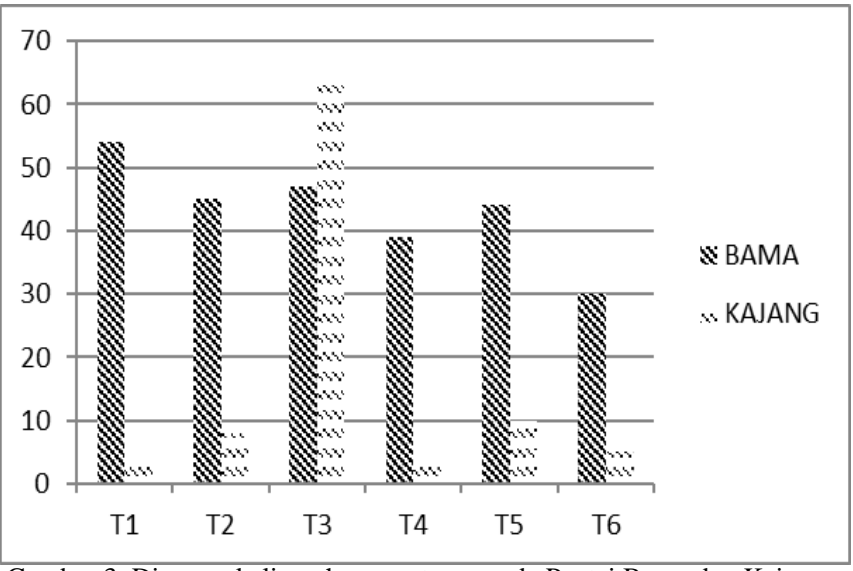

Gambar 3. Diagram kelimpahan crustacea pada Pantai Bama dan Kajang

Pada variabel jumlah jenis, di padang lamun Pantai Bama dijumpai 7 jenis crustacea sedangkan di Pantai Kajang dijumpai 6 jenis crustacea dan tidak terdapat perbedaan signifikan dalam hal jumlah jenis crustacea pada kedua lokasi tersebut. Jumlah jenis crustacea pada setiap transek di Pantai Bama dan Kajang ditunjukkan pada Gambar 4.

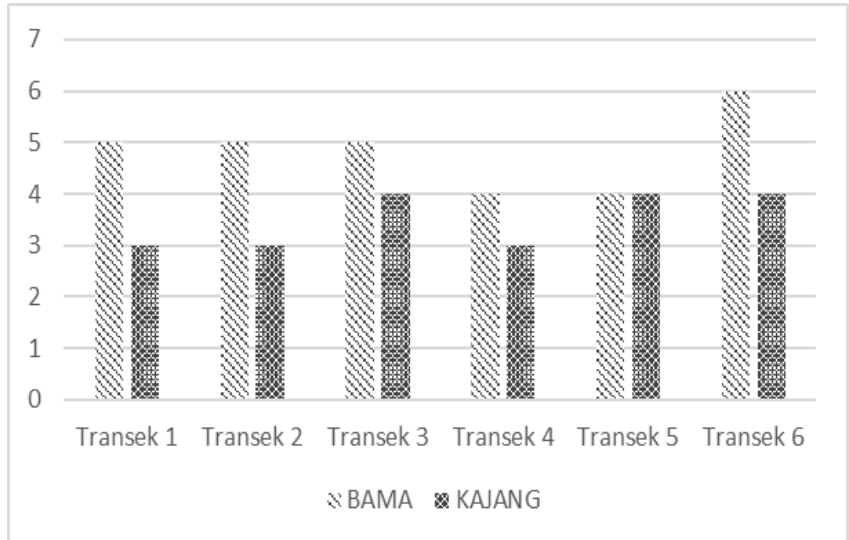

Gambar 4. Diagram jumlah jenis crustacea pada padang lamun Pantai Bama dan Kajang

Hasil dari perhitungan kelimpahan crustacea di Pantai Bama dan Kajang kemudian di analisis menggunakan uji statistik independent t-test. Pengujian ini dilakukan untuk mengetahui ada tidaknya perbedaan kelimpahan crustacea pada Pantai Bama dan Kajang. Hasil dari uji statistik ini menunjukkan hasil $p$-value uji adalah 0,021 , dimana nilai $p$ value ini lebih kecil dari 0,05 maka dapat disimpulkan bahwa ada perbedaan rata-rata yang signifikan antara Pantai Bama dan Pantai Kajang.

Kelimpahan crustacea di Pantai Bama jauh lebih tinggi dibandingkan dengan Kajang (Gambar 3). Pada area padang lamun Pantai Bama pada tiap transek ditemukan 30-54 individu yang hidup diantara tegakan lamun sedangkan pada Pantai Kajang terdapat 5-63 individu crustacea pada setiap transek. Dari Gambar 3 terlihat adanya perbedaan kelimpahan yang mencolok dimana pada transek tiga di Pantai Kajang dijumpai 63 individu dari jenis Ocypode sp. sementara pada transek lainnya hanya dijumpai 4-10 individu saja.

Hasil analisis kelimpahan crustacea pada penelitian ini bertolak belakang dengan asumsi awal dimana lokasi Pantai Bama diasumsikan memiliki kelimpahan crustacea yang lebih rendah karena memiliki tingkat aktivitas antropogenik yang lebih tinggi; namun hasil analisis justru menunjukkan bahwa kelimpahan crustacea di Pantai Bama adalah lebih tinggi daripada di Pantai Kajang.

Sebagian besar penelitian mengenai aktivitas antropogenik pada padang lamun menunjukkan korelasi yang negatif terhadap komunitas crustacea, misalnya oleh [13]yang menunjukkan bahwa area padang lamun dengan intensitas antropogenik tinggi (berupa 50 pijakan kaki per bulan) pada area seluas $12,5 \mathrm{~m}^{2}$ memiliki kelimpahan crustacea yang lebih rendah dibandingkan area dengan luasan yang sama yang memiliki intensitas antropogenik rendah atau sedang (20 pijakan per bulan).

[26]juga menyatakan bahwa aktivitas antropogenik juga berpotensi mengakibatkan penurunan keanekaragaman crustacea di padang lamun, terutama karena pengambilan jenis-jenis yang bernilai ekonomis, misalnya Penaeidae dan Portunidae. Tekanan aktivitas antropogenik di daerah pantai merupakan juga ancaman utama terhadap ekosistem padang lamun [27]. Berdasar penelitian [28] menyebutkan bahwa kemungkinan efek antropogenik berupa pijakan kaki ini tidaklah langsung. Kerusakan akibat hal ini sering kali berakibat pada patahnya bagian dari tumbuhan lamun atau alga, sehingga secara konsisten hal ini akan berakibat pada berkurangnya habitat hidup bagi fauna yang hidup berasosiasi pada daerah tersebut [28]

Bila ditinjau dari jenis yang melimpah di Pantai Bama, yaitu Kelomang Diogenidae dan Coenobitidae, maka perbedaan kelimpahan crustacea di Pantai Bama dibandingkan dengan Kajang dapat dimungkinkan disebabkan oleh faktor kebiasaan makan (food habits) dari Diogenidae tersebut.

Aktivitas antropogenik yang lebih tinggi di Pantai Bama dapat menyebabkan masuknya limbah baik organik maupun anorganik ke padang lamun sehingga akan banyak meningkatkan kandungan organik pada perairan dan daun lamun. Hal tersebut didukung hasil pengukuran materi organik yang menempel pada daun lamun yang lebih tinggi di Pantai Bama $(12,49 \%)$ dibandingkan dengan Pantai Kajang (3,78\%) [29].

Oleh karena itu maka akan lebih banyak dijumpai organisme-organisme kecil pemakan sampah dan materialmaterial yang membusuk sehingga jumlah Kelomang Diogenidae yang ditemukan pada Pantai Bama lebih banyak daripada Pantai Kajang. Pada Pantai Bama dapat ditemukan 14-106 individu Kelomang pada setiap transek sedangkan di Pantai Kajang ditemukan 3-9 individu saja.

Kelomang Diogenidae hidup diantara tegakan daun lamun atau pada helaian daun lamun dan umumnya bersifat omnivora, memangsa hewan kecil dan merupakan pemakan 
sampah atau material yang membusuk [9] [10] [24] [30] dan kadang bersifat predator bagi invertebrata yang berukuran lebih kecil [10] [31].

\section{E. Keanekaragaman Jenis Crustacea}

Pada penelitian ini, nilai indeks keanekaragaman didefinisikan sebagai jumlah jenis crustacea di padang lamun beserta kelimpahannya masing-masing disuatu area. Faktor yang mempengaruhi nilai keanekaragaman jenis adalah kondisi lingkungan, jumlah jenis dan sebaran individu pada masing-masing jenis. Hasil perhitungan nilai indeks keanekaragaman jenis Shannon-Wiener $\left(\mathrm{H}^{\prime}\right)$ dan indeks kemerataan jenis Pielou (J) disajikan pada Tabel 5.

Hasil pengukuran indeks keanekaragaman (H') Pantai Bama berkisar antara 1,03-1,30 sedangkan Pantai Kajang berkisar antara 0,24-1,36. Bila dikategorikan dalam pembobotan tingkat keanekaragaman. maka keanekaragaman kedua pantai ini tergolong rendah karena nilai H' $<2$ (Ludwig \& Reynold, 1988). Secara garis besar keanekaragaman Pantai Bama dapat dikatakan lebih tinggi daripada Pantai Kajang. Nilai dari indeks keanekaragamn Shannon-Wiener $\left(\mathrm{H}^{\prime}\right)$ ini kemudian di analisis dengan menggunakan uji statistik independent sample t-test untuk melihat ada tidaknya perbedaan rata-rata keanekaragaman di Pantai Bama dan Kajang. Hasil uji statistik indpendent sample t-test menunjukkan hasil p-value sebesar 0,246, sehingga dapat ditarik kesimpulan bahwa tidak terdapat perbedaan rata-rata indeks keanekaragaman yang signifikan pada Pantai Bama dan Kajang karena nilai p-value lebih besar daripada 0,05$)$.

Menurut [32] komunitas yang stabil akan memiliki nilai keanekaragaman yang cenderung tinggi. Namun hasil yang diperoleh di Pantai Kajang menunjukkan adanya angka yang jauh berbeda, yaitu pada transek 3 dimana nilai indeks H' sangat rendah yaitu 0,243 saja. Pada area tersebut kelimpahan cenderung tinggi namun keanekaragaman sangat rendah hal ini dikarenakan jumlah spesies pada transek tersebut cenderung sedikit dan adanya ketidakmerataan kelimpahan antar spesies yang ditemukan sehingga terdapat dominansi dari spesies tertentu pada transek tersebut. Hal ini sesuai dengan pernyataan Odum dalam [33] yang menyatakan bahwa rendahnya nilai H' dikarenakan adanya dominansi dari spesies yang tersdapat pada suatu lokasi. Untuk melihat kemerataan ini. dapat dilakukan dengan menggunakan indkes kemerataan jenis Pielou (J).

Tabel 4.

Tabel Nilai Indeks Diversitas Shannon-Wiener $\left(\mathrm{H}^{\prime}\right)$ dan Indeks Kemerataan Jenis Pielou $(J)$

\begin{tabular}{llllll}
\hline \hline Lokasi & Transek & $\mathrm{H}^{\prime}$ & Kategori & $\mathrm{J}$ & Kategori \\
\hline BAMA & T1 & 1,22 & Rendah & 0,63 & Tinggi \\
& & 9 & & & \\
& T2 & 1,30 & Rendah & 0,67 & Tinggi \\
& & 6 & & & \\
& T3 & 1,03 & Rendah & 0,53 & Tinggi \\
& T4 & 7 & & & \\
& & 3 & Rendah & 0,62 & Tinggi \\
& T5 & 1,22 & Rendah & 0,63 & Tinggi \\
& & 8 & & & \\
& T6 & 1,23 & Rendah & 0,63 & Tinggi \\
& & 3 & & & \\
KAJANG & T1 & 1,03 & Rendah & 0,58 & Tinggi \\
& & 9 & & & \\
\hline \hline
\end{tabular}

\begin{tabular}{lllll}
\hline \hline T2 & 0,97 & Rendah & 0,54 & Tinggi \\
& 4 & & & \\
T3 & 0,24 & Rendah & 0,13 & Rendah \\
& 3 & & & \\
T4 & 1,03 & Rendah & 0,58 & Tinggi \\
& 9 & & & \\
T5 & 1,36 & Rendah & 0,76 & Tinggi \\
& 6 & & & \\
T6 & 1,33 & Rendah & 0,74 & Tinggi \\
& 2 & & & \\
\hline \hline
\end{tabular}

Berdasarkan Tabel 4 menunjukkan bahwa kategori untuk indeks kemerataan jenis hampir di keseluruhan dapat dikategorikan tinggi karena nilainya mendekati 1,00 namun pada transek 3 di Pantai Kajang menunjukkan hasil yang berbeda dimana nilai $\mathrm{J}$ hanya mencapau 0,13 saja sehingga dapat dikategorikan bahwa kemerataan jenis pada ransek ini rendah. Hal ini dikarenakan pada transek tersebut jumlah spesies individu yang ditemukan relatif sedikit namun ada satu spesies yang ditemukan dengan jumlah banyak pada satu tempat yaitu spesies Ocypode sp. yang ditemukan menggerombol pada satu titik. Bila nilai J mendekati 0,00 hal ini berarti penyebaran populasi semakin tidak merata dan cenderung terjadi dominansi oleh salah satu atau beberapa speies tertentu pada area tersebut [34].

\section{KESIMPULAN}

Pada akhir penelitian dapat disimpulkan bahwa terdapat perbedaan yang signifikan dalam hal kelimpahan crustacea antara kedua lokasi; dimana kelimpahan rata-rata crustacea di padang lamun Pantai Bama adalah 51.8 individu $/ 150 \mathrm{~m}^{2}$ sedangkan di Kajang adalah 18.8 individu $/ 150 \mathrm{~m}^{2}$. Kekayaan jenis crustacea di kedua lokasi adalah setara dimana crustacea dominan adalah dari anggota famili Diogenidae (hermit crab). Nilai indeks diversitas Shannon-Wiener $\left(\mathrm{H}^{\prime}\right)$ komunitas crustacea di Pantai Bama berkisar antara 1.03 hingga 1.30 Untuk lokasi Kajang, nilai $\mathrm{H}^{\prime}$ bervariasi antara 0.24 hingga 1.36 .

\section{DAFTAR PUSTAKA}

[1] F. Yulianda, "Ekowisata Bahari Sebagai Alternatif Pemanfaatan Sumber Daya Pesisir Berbasis Konservasi," in Seminar Sains, Departemen Menejemen Sumber Daya Perairan, Fakultas Perikanan dan Ilmu Kelautan IPB, 2007.

[2] M. W. Epler, "Ecotourism: Prinnciples, Practice, And Polices For Sustainability," UNEP, 2002.

[3] Anonim, "Profil Taman Nasinal Baluran Situbondo Jawa Timur,' 2017. [Online]. Available: http://balurannationalpark.web.id/.

[4] M. N. R. N.M. Suriani, "Pemetaan Potensi Ekowisata di Taman Nasional Baluran," J. Pariwisata, vol. 24, no. 3, pp. 251-260, 2011.

[5] R. Wimbaningrum, "Pola Zonasi Lamun (Sea Grass) dan Invertebrata Makrobentik yang Berkoeksistensi di Rataan Terumbu Pantai Bama, Taman Nasional Baluran, Jawa Timur," J. ILMU DASAR, vol. 3, no. 1, pp. 1-7, 2002.

[6] F. T. S. E.P. Green, World Atlas of Seagrasses. USA: University of California Press, 2003.

[7] D. C. Hartog, Seagrasses Of The World. Amsterdam: North Holland Publishing, 1970.

[8] N. A. Campbell, Biology Concepts and Connection. California: The Benjamin Cummings Publishing Company Inc, 1993.

[9] I. Aswandy, "Biota Laut: Krustasea Sebagai Konsumen di Padang Lamun," Oceana, vol. XXXIII, pp. 1-9, 2008.

[10] I. A. M.K. Moosa, "Krustacea dari Padang Lamun di Perairan Lombok Selatan," 1995.

[11] J. J. M. F.R. Rossi, M. Forster, F. Montserrat, M. Ponti, A Terlizzi, T. Ysebaert, "Human Trampling As Short-Term 
Disturbance On Intertidal Mudflats: Effects On Macrofauna Biodiversity And Population Dynamics Of Bivalves," Mar. Biol., vol. 151, pp. 2077-2090, 2007.

[12] G. H. J. E.E. Caren, "Trampling in a seagrass assemblage: direct effects, response of associated fauna, and the role of substrate characteristics," Mar. Ecol. Prog. Ser., vol. 21, pp. 199-209, 2000.

[13] J. G. H. C.E. Eckrich, "Trampling in a Seagrass Assemblage: Direct Effects, Response Of Associated Fauna, And The Role Of Substrate Characteristics," Mar. Ecol. Prog Ser, vol. 201, pp. 199-209, 2000.

[14] P. Purwati, "Masyarakat Taksonomi Kelautan Indonesia," in Prosliding Seminar Nasional I.LIPI, 2011.

[15] K. Lampe, "Holothurian Density, Distribution and Diversity Comparing Sites with Different Degrees of Exploitation in The Shallow Lagoon of Mauritius," SPC Beche-de-mer Information Bulletin, p. 33, 2013.

[16] C. A. P.L. Collin, Tropical Pacific Invertebrates. California: Coral Reef Press, 1995.

[17] V. H. N. K.E Carpenter, "FAO Species Identification Guide For Fishery Purposes The Living Marine Resources Of The Western Central Pacific Volume 2: Cephalopods, Crustaceans, Holothurians and Sharks," Food Agric. Organ. United Nations Rome, 1998.

[18] C. B. N. Mendez, "Effects of the antidepressant fluoxetine in spiked-sediments on developmental and reproductive features of the polychaetes Capitella teleta and Capitella sp," A. Ecotoxicol., vol. 24, pp. 106-118, 2015.

[19] H. Effendi, Telaah Kualitas Air: Bagi Pengelolaan Sumber Daya dan Lingkungan Perairan. Yogyakarta: Penerbit Kanisius, 2003.

[20] G. P. J. M.J. Keough, "Seagrass meadows and their inhabitants," in Underwood AJ, Chapman MG, editor, Coastal Marine Ecology of Temperate Australia, Sydney: UNSW Press, 2000, pp. 221-239.

[21] S. O. R.J. Orth, T.J. Carruthers, W.C. Dennison, C.M. Duarte, J.W. Fourqurean, K.L. Heck, A.R. Hughes, G.A. Kendrick, W.J. Kenworthy, "A Global Crisis For Seagrass Ecosystems Bioscience," vol. 56, 2006

[22] L. J. McKenzie, Seagrass Educator Handbook. Australia: Seagrass-Watch, 2008.
[23] P. H. N. I. Nagelkerken, C.M. Roberts, G. Van der Velde., M Dorenbosch, M. C. Van Riel, E. Cocheret de la Moriniere, "How important are mangroves and seagrass beds for coral-reef fi sh? The nursery hypothesis tested on an island scale," Mar. Ecol. Prog. Ser., vol. 244, pp. 299-305, 2002.

[24] R. Pratiwi, "Asosiasi Krustasea di Ekosistem Padang Lamun Perairan Teluk Lampung," Ilmu Kelaut., vol. 15, no. 2, pp. 59118,2010

[25] Susetiono, "Fauna Padang Lamun Tanjung Merah Selat Lembah," Jakarta, 2004.

[26] M. G. L.M. Nordlund, "Biodiversity loss in Seagrass Meadows Due to Local Invertebrate Fisheries and Harbour Activities," Estuary Coast. Shelf Sci. Abbr., vol. 135, pp. 231-240, 2013.

[27] K. Amri, "Sinekologi Padang Lamun Akibat Tekanan Antropogenik: Studi Kasus Pulau Barranglompo dan Bonebatang Kepulauan Spermonde Sulawesi Selatan,” IPB, 2012.

[28] A. C. D. Casu, G. Ceccherelli, "Imeddiate Effect of Experimental Human Trampling on Mid-Upper Intertidal Benthic Invertebrates at the Asinara Island MPA (NW Mediterranean)," Hydrobiologia, vol. 555, pp. 271-279, 2006.

[29] R. A. Prayogi, "Studi Keanekaragaman dan Kelimpahan Meiofauna Epifit pada Daun Lamun di Lokasi Ekowisata Pantai Bama dan Pantai Kajang Taman Nasional Baluran,” 2018.

[30] Y. I. Dewiyanti, "Identifikasi dan Kelimpahan Hama Penyebab Ketidakberhasilan Rehabilitasi Mangrove," J. Ilmu Kelaut. Undip, 2013.

[31] L. E. . B. F.B. Ribeiro, H.M. Cascon, "Predatory Behavior of the Paguroid Dardanus venosus (H. Milne-Edwards, 1848) (Anomura: Diogenidae) on the Snail Aurantilaria aurantiaca (Lamarck,1816) (Gastropoda: Fasciolariidae),” J. Brazilian Crustac. Soc., 2017.

[32] A. S. Ibadah, "Struktur Komunitas Juvenil Ikan Dan Ikan Kecil Pada Ekosistem Mangrove Dengan Sistem Perakaran Berbeda Di Kecamatan Sepulu - Madura," ITS, 2017.

[33] H. Setiawan, "Status ekologi hutan mangrove pada berbagai tingkat ketebalan," J. Penelit. Kehutan. Wallacea, vol. 2, no. 2, pp. 104-120, 2013.

[34] M. Ferianita-Fachrul, Metode Sampling Bioekologi. Jakarta: PT. Bumi Aksara, 2007. 